\title{
Ebolavirosis: a 2014 Review for Clinicians
}

\author{
Ebolavirose: uma Revisão de 2014 para Clínicos
}

Jaime NINA ${ }^{1,2}$

Acta Med Port 2014 Sep-Oct;27(5):625-633

ABSTRACT

Ebolavirosis, like Marburgvirosis, are African zoonosis, and for both the primary animal reservoir are bats. It is a typical acute haemorrhagic fever, characterized by a high lethality rate. In an outbreak, the human index case became infected after contact with an infected animal or its blood, in most cases during hunting. Secondary human cases became infected after close contact with another human case, with infected human fluids or with a recent dead corps of a human case. These viruses are easily transmitted by direct contact or by contact with patient body fluids, mainly blood. As such, health professionals working under suboptimal conditions usually constitute a large share of Ebola victims. At the moment, the treatment is only supportive, but several drugs are almost ready to be tried in human trials. There is no vaccine approved, but again there are several very promising in the pipeline.

Keywords: Ebolavirus; Hemorrhagic Fever, Ebola/diagnosis; Hemorrhagic Fever, Ebola/epidemiology; Hemorrhagic Fever, Ebola/ epidemiology/prevention \& control; Hemorrhagic Fever, Ebola/epidemiology; Hemorrhagic Fever, Ebola/therapy.

\section{RESUMO}

A Ebolavirose, tal como a Marburgvirose, são zoonoses africanas, e para ambas o reservatório animal primário são morcegos. São febres hemorrágicas agudas típicas, caracterizadas por uma elevada taxa de letalidade. Num surto, o caso index humano infecta-se por contacto com um animal infectado, na maioria dos casos numa caçada. Os casos humanos secundários infectam-se por contacto próximo com um caso humano, com os seus fluidos corporais ou com um cadáver recente de um caso humano. São vírus que se transmitem facilmente por contacto directo com um caso infectado, ou por contacto com os seus fluidos corporais, basicamente com o sangue. Por isso, profissionais de saúde a trabalhar em condições subóptimas constituem uma percentagem elevada das vítimas do Ébola. De momento, o tratamento disponível é apenas de suporte, mas vários fármacos serão ensaiados em humanos a curto prazo. Também ainda não existe vacina aprovada, mas várias prometedoras já se encontram no pipeline.

Palavras-chave: Ebolavirus; Febre Hemorrágica do Ebola/epidemiologia; Febre Hemorrágica do Ebola/diagnóstico; Febre Hemorrágica do Ebola/prevenção \& controlo; Febre Hemorrágica do Ebola/tratamento.

\section{Aetiology}

Ebola virus is classified into the family of Filoviridae, a name that in a literal translation means something as 'virus like a rope', 'virus like a twine' or 'virus like a string'. And when we look at an electronic microscopic image of these viruses we agree at once with the name (Fig.1).

This viral family ${ }^{1-5}$ has two genera of medically important virus: Marburgvirus and Ebolavirus. All Marburgvirus known, or at least studied, are classified into a single species, Marburgvirus lakevictoria. On the contrary, Ebolavirus are classified into at least five different species, Ebolavirus Zaire, E. Sudan, E. Cote d'Ivoire, E. bundibugyo and $E$. reston. But we should remember that the classification of life forms into different species was originally invented to classify sexually reproducing animals and plants, while virus use a completely different way of 'reproducing'. So this way of classification is ill adapted to handle virus, so much that the limits of genera, species and strains in virus are fuzzy and poorly defined.

Marburgvirus are very similar to Ebolavirus: in lifecycle; in the primary animal reservoir (the only difference is that the Marburgvirus' bats are bats species adapted to open forest, or the transition forest / savannah, or gallery forest, while Ebolavirus' bats are bat species adapted to deep rainforest); in ways of transmission, including the high risk of nosocomial transmission; in clinical presentation and evolution, including the high lethality rate; in the diagnosis problems and techniques; in the treatment (or lack of it); in outbreak control measures; and in prevention measures. As such, usually they are studied and presented together.

Ebolavirus reston is a poorly studied and even more poorly understood virus. ${ }^{1,2,6,7}$ It was found in pigs in Philippines, in China and in Taiwan, and also in laboratory monkeys imported from a monkey breeding facility in Philippines. Apparently all E. reston infected pigs were also infected at the same time with a second completely different virus, the PRRSV, or pig respiratory-reproductive syndrome virus, locally known as 'disease of the blue ears'. Even stranger, some of the facility workers had serological evidence of a prior Ebolavirus infection, but no disease or history of any compatible disease. A defective virus? An exclusively animal virus? At this moment we simply don't know.

E. Cote d'Ivoire (in American papers sometimes called E. tai, from the name of the Ivory Cost's National Park and forest where it was isolated) and $E$. bundibugyo were

1. Serviço de Doenças Infecciosas e Medicina Tropical. Hospital Egas Moniz. Centro Hospitalar Lisboa Ocidental. Lisboa. Portugal.

2. Unidade de Clínica. Instituto de Higiene e Medicina Tropical. Universidade Nova de Lisboa. Lisboa. Portugal.

Recebido: 19 de Agosto de 2014 - Aceite: 03 de Outubro de 2014 | Copyright @ Ordem dos Médicos 2014 


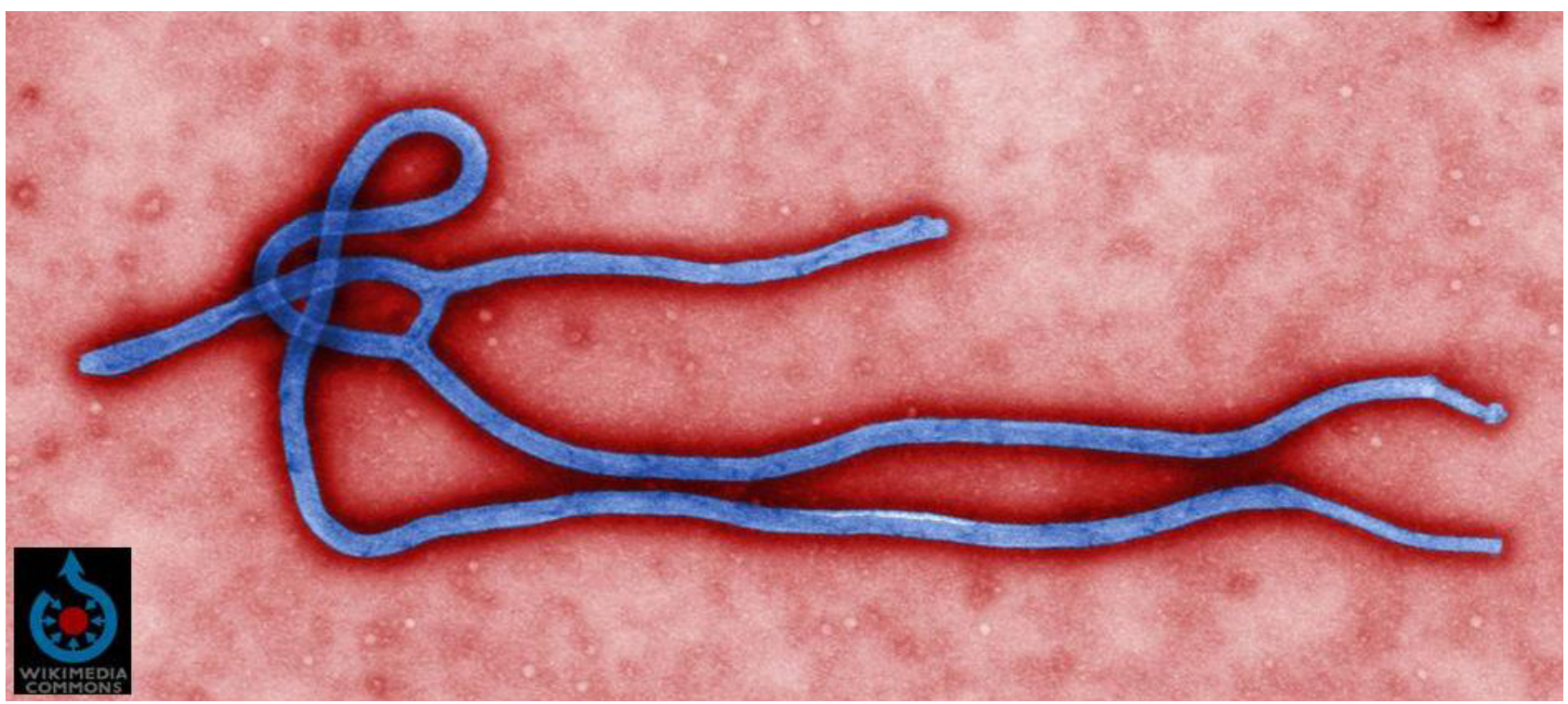

Figure 1 - Ebola virus electron microphotograph, from Wikipedia

isolated in single outbreaks, and the small number of cases didn't allowed more than the simple observation that they look and behave very like the Ebolavirus Zaire. Ebolavirus Sudan, before the Ebola's West Africa 2014 outbreak, was the cause of about $1 / 3$ of the Ebolavirus outbreaks (in South Sudan and Uganda) and $1 / 4$ of all Ebola virus deaths, and, perhaps except by the slight lower lethality rate, looks very similar in all aspects to Ebolavirus Zaire.

Ebolavirus Zaire was the first to be isolated and studied (in a 1976 outbreak in a small village at the bank of Ebola river, on the far NE of Zaire, also called Congo Kinshasa, near the South Sudan border); it is the one with the wider distribution; and is the one responsible for the majority of outbreaks, cases and deaths. Except when stated otherwise, in all the remainder of this paper every time I speak of Ebola virus, I am speaking of Ebolavirus Zaire.

Ebola virus are RNA viruses, with a single strand, single segment, negative reading genome, one non structural and seven structural genes, membrane enveloped, and a flexible cylindrical shape with a constant diameter of $80 \mathrm{~nm}$ and a variable length of 200 to $10000 \mathrm{~nm}$ (on average 800 $1000 \mathrm{~nm}$ ). In the general structure, intra-cell lifecycle and the virion assembly sequence, Filoviridae and Rhabdoviridae (the virus family that includes the rabies virus) have many similarities but also important differences. They are cytoplasmatic virus, i.e., they complete all their lifecycle in the cytoplasm, without ever entering the nucleus. The main target cells are endothelial cells and macrophages, but many other cell lines, tissues and organs can also be infected.

Filovirus are characterized by a furious replication rate - at the peak of infection a significant proportion of the total body mass of the patient and even more of the blood mass, is constituted of virion particles. This fact helps to explain both the severity and high lethality of the infection, and the facility of transmission by close contact, particularly with patient blood.

\section{Epidemiology}

Ebolavirosis are a group of zoonosis, infections able to jump among several different hosts..$^{1-4}$ Hundreds of mammal species had already been found infected with Ebola virus, however not a single case of a non mammal animal has been reported infected - apparently birds, reptiles, insects, and all other non mammal animals are naturally resistant to infection with these virus. Among the mammals, two patterns of infection are patent: bats are able to be infected and infectious apparently for life, with no symptoms,

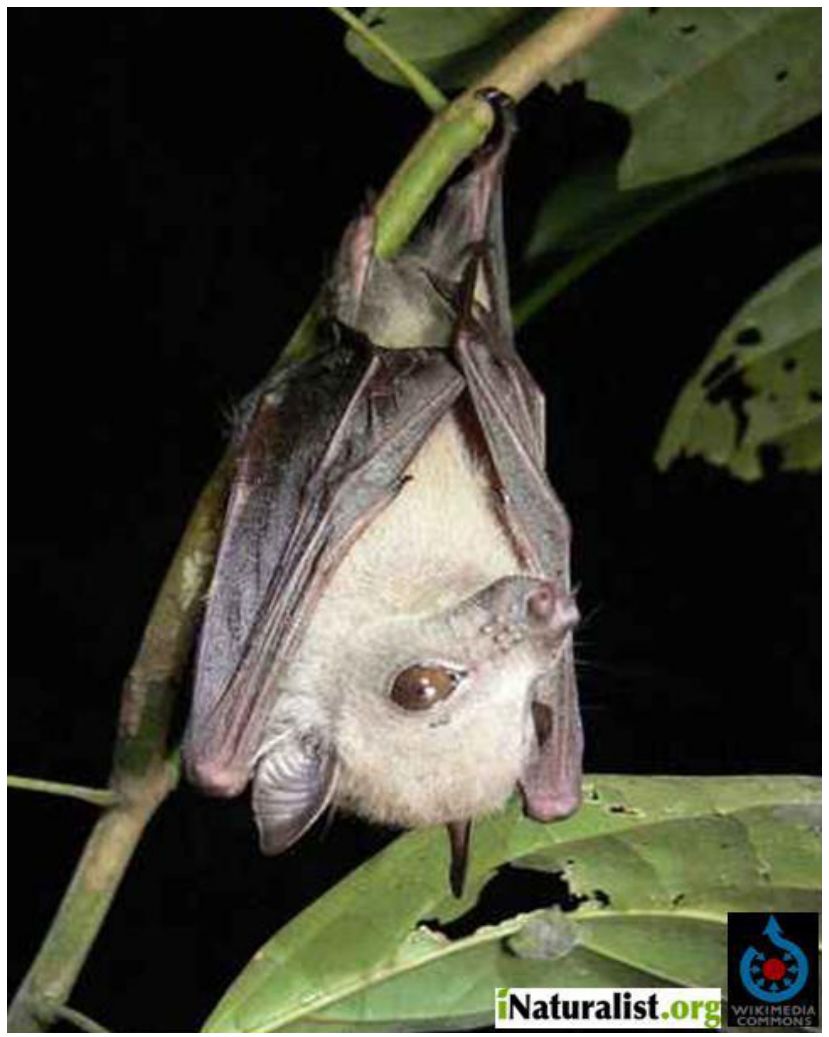

Figure 2 - Ebola virus main's bat host, the flying fox Myonycteris torquata, in a photograph from Wikipedia 
remaining perfectly healthy even when spreading virus to other bats or to other non bat mammals. On the contrary, Ebola virus infection in non bat mammals generally causes a severe disease, an acute haemorrhagic fever, with a high lethality rate. The few animals that survive this acute disease are believed to become immunized, and protected for life against a second infection with the same Ebola virus species.

The main primary animal reservoir of Ebolavirus are three bat species, a big fruit eating bat (a 'flying fox') Myonycteris torquata (Fig. 2), the one implied in the West Africa outbreak, and two other rarer fruitbats, Hepomops franquetti and Hypsignathus monstrosus. ${ }^{8,9}$ All three live in deep rainforest, and if we put the geographic location of Ebola outbreaks on top of a forest cover map of Africa, we realise that all outbreaks started in these bats' country, ${ }^{1}$ including this last West Africa epidemic (Fig. 3). These bats have been found infected only with Ebolavirus Zaire, so we are not sure if the other Ebolavirus species use the same bats species as hosts. We know however that the bat species host of Marburgvirus are different: one is also a big fruitbat, Rousettus aegyptiacus, but two others are small insectivorous bats Miniopterus inflatus and Rhinolophus eloquens. ${ }^{10,11}$ There are no frequent contacts between people and bats - these animals are nocturne, silent (at sound frequencies our ears are able to ear), difficult to spot, and even more difficult to catch. But bats can infect other wild animals, like monkeys, of which some species are very fond of eating bats, if they managed to catch one - and people regularly hunt and eat monkeys.

Once one human becomes infected, for example a hunter or his wife when cooking, the virus can spread easily from person to person by close contact - and another Ebola epidemic has started.

This virus lifecycle is summarized in the beautiful image published by US' CDC, ${ }^{2}$ (Fig. 4).

From the first known outbreaks, in 1976 both in NE Zaire and across the border in South Sudan, until now, ${ }^{1}$ all human Ebola outbreaks were localized in the Congo basin and nearby areas (Fig.3). The 2014 West Africa outbreak was the first in this part of Africa, catching by surprise the local health services. It was also the first to spread to more than one country, and by far the largest until now - at the moment of writing (August 2014), its number of cases and of deaths has already surpassed the equivalent numbers of all other Ebola outbreaks add together. ${ }^{12}$

\section{Transmission}

Filovirus are fragile., ${ }^{1,2,13}$ Outside a host they die fast. They are very susceptible to radiation, both natural sunlight and ultraviolet artificial light, and when exposed to them they die in minutes. They are also very susceptible to a long list of chemicals, including very common ones like alcohol, almost all antiseptics, even vulgar soap. Heat is another way of killing these virus, they die in a few minutes at $60^{\circ}$ C. However, they tolerate well cold, and are able to survive indefinitely when frozen or dry frozen.

This means they can't afford to stay more than a few moments outside a host - they are able to be transmitted only by close contact, or staying inside a protected environment, like blood or a dead corps.

The first case (index case) in a human outbreak is someone with a close contact with an infected animal this is well exemplified by the 2014 DR Congo outbreak ${ }^{1}$. According to the information from World Health Organization (WHO), in this outbreak the index case was the wife of a hunter, who, completely unaware of the danger, butchered and cooked a wild sick animal killed by her husband - of course without using gloves or any other protection.

Secondary cases are infected by close contact with the

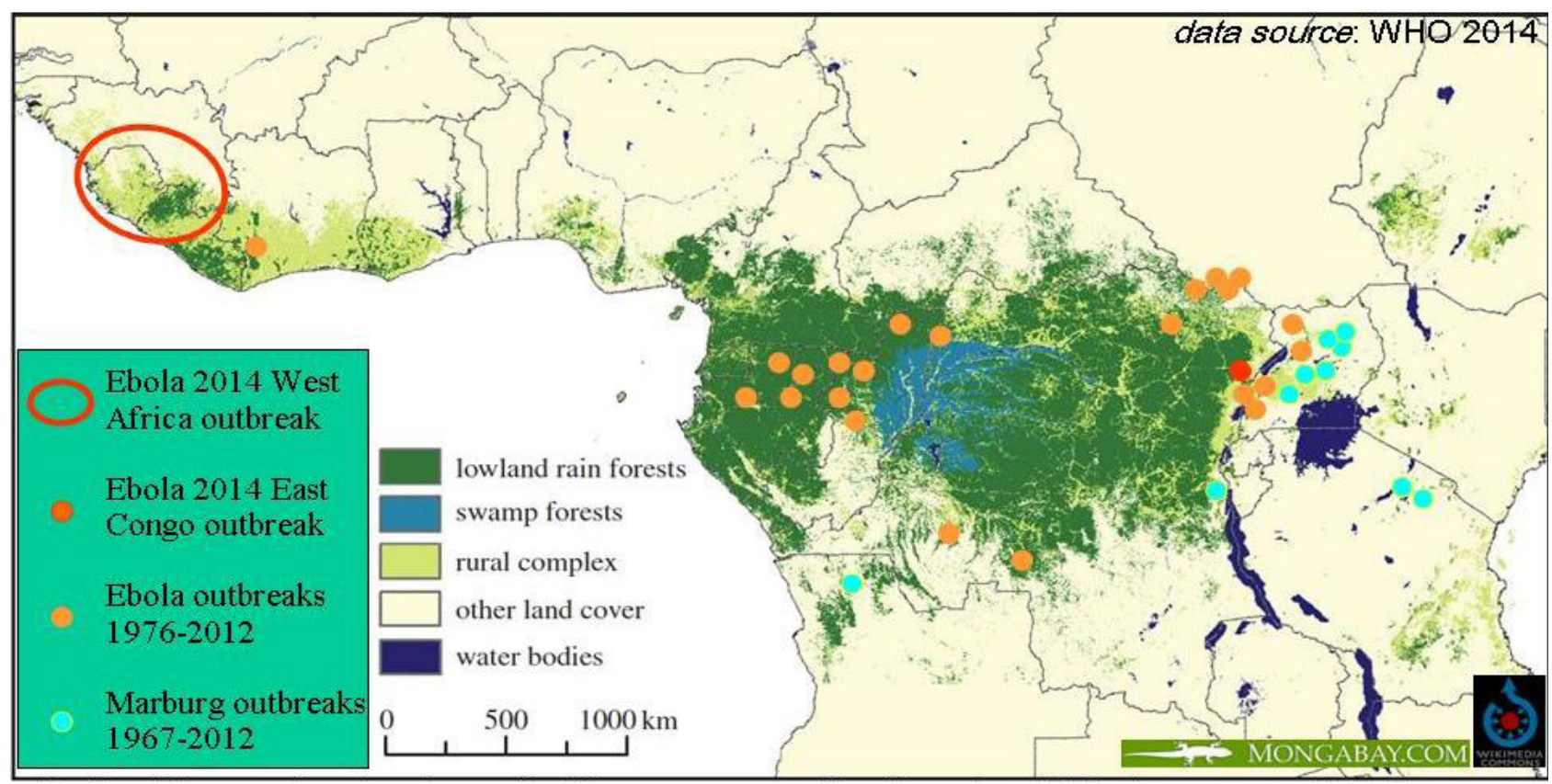

Figure 3 - Geographic location of all known original outbreaks of Ebola virus and Marburg virus 


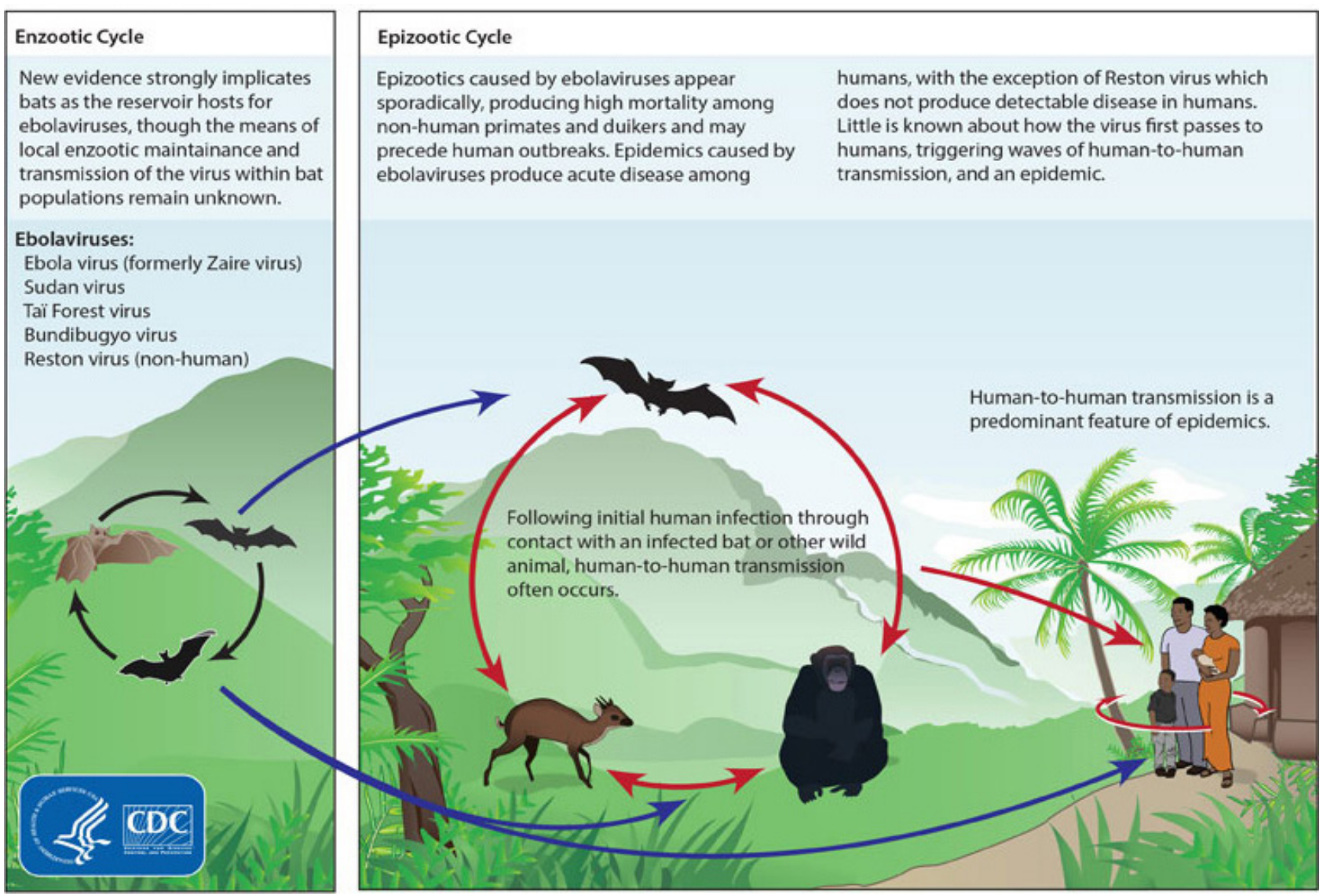

Figure 4 - Ebola virus ecology (from US' CDC)

index case, with other secondary case, with blood or other body fluids of sick infected patients, or even when handling the bodies of the Ebola victims. Again, the 2014 DR Congo outbreak $^{1}$ is a good example: the first secondary cases were the children of the index case, others same house relatives, the local health workers who try to care for her and the persons who prepare her body for the burial.

The most infectious, therefore the most dangerous patient, is the one with haemorrhages in the respiratory tree or in the mouth, and with cough accesses: each time this patient cough, he or she spread into the nearby space an aerosol of very small blood droppings full of infectious virus particles.

Ebola virus can reach a very high concentration in the blood of patients, so handling blood from them can be very dangerous. Among the nosocomial infectious agents dangerous to health professionals, Ebola virus are very near the top, alongside with Marburg virus, Lassa virus and the plague bacterium. Even worst, Ebola virus are infections of very poor countries, where usually protection equipments simply don't exist, at least not until the alarm of an Ebola outbreak is given and the international organizations start contributing with this kind of equipment. Also, the local laboratories almost always lack the most rudimentary safety equipment, protocols and training.

Besides close relatives and health professionals, the third group more in danger of be infected during an outbreak, is the funerals personal, either professionals, religious or family members who volunteer to prepare, dress and do the burial of the dead patients.

It is also important to be aware of the ways Ebola virus is not transmitted. ${ }^{1,2,13}$ There wasn't reported a single case of Ebola virus infection acquired by contact, however close, with an infected patient in the incubation period. As well, surviving patients who no longer have fever, haemorrhages or cough, and of course convalescent patients, are not infectious. The only exception already detected is the possibility of transmission by sexual contact, and only for a couple of months after the convalescent patient became asymptomatic. As well, no cases have been reported of infection by casual contact, even with a symptomatic patient but without haemorrhages: no cases were found among professionals or passengers from airport, air travel, bus or taxis who happened to share the space with a travelling Ebola patient. Also there is no report of infections being acquired by contact with inert objects touched by an Ebola patient but clean of blood or other body fluids.

\section{Clinical presentation}

Ebola virus infection ${ }^{4,14,15}$ has a short incubation period, usually around one week, $3 / 4$ of the cases between 5 and 10 days, with the extremes at 2 and 20 days.

The evolution is typical of a severe haemorrhagic fever. The onset is sudden, with fever, headache, muscle and joint pain, sometimes nausea, vomits and/or diarrhoea without blood. The patient usually complains of extreme prostration: 
as an example, the Liberian Ebola patient who air travelled to Nigeria and started the outbreak there, felt so tired that he lied down on the airport floor careless of what the other passengers might think.

After a couple of days the fever goes up even more and a rash may be apparent. It is a macular rash, not always evident, particularly in dark skins. Another day or so, and the haemorrhages start: vomit and/or diarrhoea with blood, petechiaes on the skin, eye's conjunctives or mouth mucosa. Cough and dyspnoea may follow, with more bleeding from mouth, nose, respiratory tract, skin, urine, anus, vagina, eyes and so on. And soon after the picture evolves to massive internal bleeding, but fortunately at this time almost always the patient is already in coma. The patient usually dies from the exsanguination and shock, or from brain haemorrhages, from seizures or from multiorgan failure.

If the disease evolution happens to be slightly slower, the patient's immune response may catch up (particularly in children). If the patient is lucky enough not to be killed in the meantime by a brain haemorrhage or a massive internal bleeding or any other deadly complication, at the third week the patient starts to improve: the fever goes down, the bleeding slowly stops and the patient starts to feel better and believing he or she is going to survive. The Ebola disease in the survivors is accompanied by a massive weight loss, and the convalescent period takes several weeks, even months. Sequels are rare, the less rare being deafness (usually unilateral) and orchitis. If a female patient is pregnant and survives, the risk of pregnancy loss is high. As far as it is known, the survivors keep a strong immune response to the same Ebola species, and it is believed they are protected for life against a second Ebola infection of the same species. It is not known how much protection, if any, this immunity confers against infection with other Ebola virus species.

The routine laboratory findings are unremarkable: low, sometimes severely low platelet count, low lymphocyte count often with circulating immunoblats, and latter on coagulation changes, anaemia and sighs of impending organs failure, with raised hepatic, renal and pancreatic markers

\section{Diagnosis}

Sporadic cases are almost impossible to be clinically diagnosed. Even the syndrome diagnosis of haemorrhagic fever is not easy: several much more common diseases like malaria, typhoid fever, meningococcal sepsis, and so on, may present themselves in a very similar way. Even other African viral haemorrhagic fevers are more common, such as yellow fever, dengue haemorrhagic fever or Lassa fever. And of course Marburg and Ebola are completely undistinguishable, without specific laboratory tests.

Given the danger of nosocomial transmission, after the first case of Ebola haemorrhagic fever has been diagnosed, all other fever cases with contact within the relevant time window with the first case shall be considered as Ebola cases until proved otherwise. ${ }^{1,2}$ And the same with proved or suspect secondary cases.

However, we shall remember that the other diseases don't disappear simply because there is an Ebola outbreak going on, so the relevant clinical examination and diagnostic tests must be performed. In other Ebola outbreaks, some deaths ${ }^{4}$ were retrospectively diagnosed as malaria in patients suspected (but latterly not confirmed) of Ebola virus infection and as such put on strict isolation without a proper clinical and laboratory evaluation.

A specific diagnosis of Ebola infection can be done with one of five kinds of diagnostic laboratory tests. ${ }^{1,2,13,15}$ The first to be developed were serological assays. A commercially available anti-Ebola IgM ELISA turn positive within days of infection, in some cases even within the incubation period, so it may be useful to diagnose acute cases. However, antiEbola IgG only turn positive latter, so their usefulness is mainly to retrospective diagnosis in convalescent survivors. In most cases the first test to turn positive in the evolution of the infection, already at the end of the incubation period, is an antigen-capture ELISA assay. For countries unable to buy it, both WHO and the US' CDC are supposed to provide it on short notice.

PCR (polymerase chain reaction) is a wonderful diagnostic tool, very sensitive (what allow it to turn positive in the evolution of the infection even before antigen detection turn positive) and very specific, allowing a species diagnosis. However, it is expensive, relies on sophisticated laboratory equipment and personal, and as such it is difficult to implement in low income countries wider than central laboratories of the country capital.

Immunohistochemistry testing may be done either at a local central laboratory or abroad, at frozen samples from deceased patients, and may be useful for retrospective diagnosis, in spite of its high cost and relatively high sophisticated laboratory equipment and personal needed.

All four kinds of Ebola tests above described can be done on inactivated samples - in fact, in Ebola suspects, samples shall always be handled only after being sure the samples have been inactivated, because of the nosocomial transmission danger. On the contrary, the last and gold standard of Ebola virus diagnosis only can be done on viable samples: viral culture. But handling viable viral samples and viral culture in Ebola case is an extremely dangerous activity. It imposes ${ }^{1,2,13}$ the highest level of biosafety transport and, of course laboratories. These kinds of high biosafety laboratories, the so called P4, are extremely expensive to built and to run, and they only exist in small numbers in a very few number of countries (in whole Europe there are only seven P4 at this moment).

Any sample containing viable Ebola virus send to a laboratory shall have the diagnosis written very clearly and shall abide by the highest biosafety transport standards. Before the sample is sent, the receiving laboratory shall be given an appropriated notice, or a previous appropriated agreed channel shall be activated. That is the case with Portugal, where the National Reference Laboratory for 
these pathogens at the Instituto Nacional de Saúde Doutor Ricardo Jorge is part of a European Network for handling dangerous pathogens.

\section{Treatment}

In haemorrhagic fevers in general and in Ebola infection in particular a meticulously attentive and methodical nursing and medical care is of upmost importance. ${ }^{4,14,15}$ In Ebola infection most of deaths are from easily prevented or treatable complications, like acute anaemia, seizures, hypovolemic shock, even dehydration. But, of course, the danger of nosocomial transmission, the lack of accurate information, the poor training, the overburden of work, the lack of protective equipment, the general panic in the population and among the professionals and their families, all conspire to the patients' high risk of being more or less "abandoned" in their isolation facilities. The difference in quality of care translates immediately in a huge difference in the lethality rate. This is well exemplified in the other filovirosis, Marburg infection: the outbreak where the virus was first discovered, and the only filovirus infection outbreak in developed countries, in 1967 in Germany and in the former Yugoslavia (started in a research facility where infected green monkeys had been imported from Uganda) had a lethality rate of $22 \%$ ( 7 deaths in 32 cases), ${ }^{1}$ but in the 1998-2000 Durba mine outbreak in Congo the lethality was $83 \%$ (128 deaths in 154 cases) ${ }^{1}$ and in the 2004-2005 Uíge outbreak in Angola the lethality rate was $88 \%$ (329 deaths in 374 cases) ${ }^{1}$ - the same virus! Even considering that in Africa probably a number of mild cases were not diagnosed and/or reported, ${ }^{1}$ what means the 'true' lethality rates were probably lower than the above reported ones, this huge difference can be considered a direct consequence of the quality level difference in nursing and supportive medical care.

Even if it is not possible to overemphasize the importance of the quality of nursing and supportive medical care in Ebola disease, everybody look for an aetiological, antiviral treatment. None is approved, yet.

However, there are several possible treatment strategies in development. Speaking only of the ones that have already shown promising results on animal trials, in fact there are four different kinds of specific antiEbola treatments: serotherapy, nucleoside polymerase antagonists, interference or anti-sense RNA (siRNAs) and coagulation cascade antagonists.

Serotherapy is an old and prestigious anti-infective therapy. In fact, its invention was considered so important, that its author, Emil Adolf von Behring (1854-1917), was given the first Medicine Nobel Prize ever, in 1901 - it revolutionized the treatment and the outcome of diseases like diphtheria and tetanus. Even today, more than a century later, every physician who does emergency service has already used anti-tetanus sera or immunoglobulin to treat wounded patients, or anti-rabies sera or immunoglobulin to treat dog-bitten patients, or anti-HBV immunoglobulin in patients exposed to hepatitis $B$, and so on. Not surprisingly, it was also the first specific anti-Ebola treatment to be tried. In the 1995 Kikwit Ebola outbreak in Congo ${ }^{16}$ several patients later on in the outbreak were treated with blood transfusions from patients who had survived early on in the same outbreak, whose blood had high anti-Ebola titres but were Ebola antigen negative and who voluntaried to give their blood. The conditions were bad, it was a very small number of treated patients and no controls were used however, only one in eight treated patients died (lethality rate of $12.5 \%$, compared with $81 \%$ for the epidemic total: 254 deaths in 315 cases), ${ }^{1}$ and the physicians, the patients and their families had the feeling it helped. Later on, the US' CDC used a small animal (mice) model to try this treatment in a more controlled experimental environment. ${ }^{17}$ Again it worked, even in immunodeficient animals. It is a little surprising that none of the three major affected countries in the 2014 West Africa outbreak have not tried it yet - but, of course, a pre condition to implement this kind of treatment is a well working blood bank - perhaps that's the bottleneck point.

In developed countries serotherapy for tetanus, diphtheria, rabies, hepatitis $B$, etc, moved from large animals produced polyclonal sera to specific monoclonal antibodies (mAbs). They are much safer, and if produced in large quantities they are also less expensive, are easy to standardise and their production doesn't need live large animals. The same is happening in Ebola. Several products are already on the pipeline. The ZMapp ${ }^{\circledR}$ is at the front, and it is a cocktail of three mAbs, selected for their high antiEbola potency, originally produced in guineapigs that had been immunized against Ebola virus. ${ }^{18}$ The genes coding these mAbs were excised from the animals and transferred to the genome of a tobacco plant, which produces them in huge quantities. After they are purified from the protein mixture of the tobacco leaves, they are resuspended in an appropriated media and they are ready to be used into Ebola patients. At the time of the West Africa Ebola outbreak alarm, ZMapp ${ }^{\circledast}$ had already been tested with good results in Ebola infected rhesus monkeys, ${ }^{18,19}$ and it was waiting FDA approval for human testing. So it was a small step for ZMapp $^{\circledR}$ to be used in the two Ebola infected Americans working in Liberia, with the good results known ${ }^{20}$ (even if not so good in the next few patients tried). An advantage of $Z$ Mapp ${ }^{\circledR}$ is how easy its production can escalate to industrial levels, because it is produced in a plant.

Another drug has already recently received FDA's green light to advance to human compassionate trial $^{21}$ in the 2014 West Africa Ebola outbreak. It is called TKM-Ebola ${ }^{\circledR}$ and it is a mixture of three small interfering RNAs (siRNAs), laboratory produced and targeting the Ebola virus polymerase and the two structural proteins VP24 and VP35.,22,23 In small trials both in guineapigs ${ }^{22}$ and in rhesus monkeys ${ }^{23}$ TKM$E^{E b o l a}{ }^{\circledR}$ proved to be high protective against a usually lethal challenge with live Ebola virus. However, no siRNA therapy (or in fact, any therapy based on manipulation of the so called 'genomic immunity') has ever been tried in humans, in any disease. Even animal trials are few and small and 
only in a limited number of infections. So, a human trial in African field conditions in a difficult infection like Ebola is a very high challenge.

Artificial nucleosides that competitively antagonize the natural ones on the viral polymerase are mainstream antiviral therapy, from the old days a generation ago, of treating herpes encephalitis with Ara-A, to the tens of million that now everyday use NRTIs as backbone to their anti-HIV therapy. Not surprising, they were also tried in Ebola virus infection. The first to be tried was ribavirine, a guanosine antagonist (not unlike other guanosine antagonists like acyclovir, abacavir and others) with impressive results in both Lassa haemorrhagic fever and South American haemorrhagic fevers (also used in hepatitis C) - but the results in Ebola virus were not impressive at all. So other nucleosides, both some already on the market and newly synthesized ones, were tried. The most promising of them is called BCX4430, and it is the product of collaboration between American military at the US Army Medical Research Institute of Infectious Diseases (USAMRIID) and an industrial partner, the BioCryst Pharmaceuticals Inc. It is a nucleoside analogue competitive antagonist of adenosine (like didanosine and tenofovir, among others) and in vitro showed to be high active against filovirusis, and also to be a broad spectrum antiviral, active against flavivirusis, bunyaviruses, arenavirusis, coronavirusis and paramyxovirusis. In vivo, its results were again impressive, given complete protection both in rodent models and in cynomolgus monkeys, ${ }^{24}$ even when it was given as late as $48 \mathrm{~h}$ after an intravenous challenge with Marburg virus. If the human trials confirm these animal data, that may be a revolution in the treatment of viral haemorrhagic fevers - an etiological treatment that works in all major haemorrhagic fevers virus! At the moment of writing (August 2014) it is waiting FDA approval for human trials.

The last treatment approach is not targeting the virus itself, but the coagulation cascade where Ebola virus produces havoc. For the moment known as rNAPc2, it is a blocker of fVIla/tissue factor and the logic behind its use is the high level of overexpression of the procoagulant tissue factor in filovirus infections, what suggests the blockage of the tissue factor pathway may be useful for the treatment of these diseases (this product has also been tried in some cancers and in cardiovascular events). Curiously, it was originally isolated from the saliva of Ancylostoma caninum, the dog's hookworm, who use it to keep blood running, without coagulate, for its convenient meal. rNAPc2 has been tried on a rhesus monkey model of Ebola infection ${ }^{25}$ and it delayed the appearance of disseminated intravascular coagulation (DIC is an important complication and cause of death in filovirus infection) and showed to reduce the lethality rate in $1 / 3$. Perhaps not a 'magic bullet' but it may be useful, at least for patients where DIC is an important contribution the severity of disease and danger of death. In conclusion, it seems likely that in only a few years we will no longer say "Ebola infection has no treatment".

\section{Prevention}

As it is usual with zoonosis, Ebola infection primary prevention is very difficult, at least until an Ebola vaccine be developed. The rule not to handle, ${ }^{1}$ without protection, wild animals found death or sick is a good one, but difficult to implement, particularly in countries where hunger is never far away.

After a first case of Ebola disease has been diagnosed, things are simpler, at least in theory. All proved or suspect cases shall be immediately isolated, ${ }^{1,2,13}$ only contact isolation if they have no cough and no haemorrhages, full respiratory isolation if they have. It is important to confirm the diagnoses in suspected cases as soon as possible (and quickly free from isolation all found negative), and as well to excluded alternative diagnosis. The isolation measures shall be rigorously followed by all but without prejudice of an attentive patient care. All persons that approach an Ebola patient, be health professionals, religious professionals, burial professionals, cleaning professionals, patient's family members, or any other, shall always use full protective equipment and strictly follow safety protocols, as well detailed described in both $\mathrm{WHO}^{26}$ and, for Portugal, DGS professional norms. ${ }^{27,28,29}$ The importance of these precautions is well illustrated by the contrast in the, according to $\mathrm{WHO}$, about $10 \%$ of West Africa's Ebola outbreak cases being local health professionals; ${ }^{12}$ and the statement done on a TV interview ${ }^{30}$ by a Médecins sans Frontières responsible that in more than 30 years of fighting Ebola outbreaks all over Africa and caring for thousands of patients his organization never had a single case of an infected member. The difference is MSF professionals are well trained and always work well protected, what, unfortunately, is not the case of the local professionals.

Particularly dangerous and as such important to be very careful, is blood handling, ${ }^{1,2,13}$ both blood collecting for diagnosis and blood vessels channelization for treatment never forgetting blood transfusions, whole blood or platelets concentrated or other blood components, are an upmost important part of treatment of Ebola patients.

Besides the patients, suspect or confirmed, it is also important the search, screen and follow up of all possible contacts $^{1,2}$ - what is much more easy to say than to do. If an Ebola outbreak has already reach a certain level of spread, quarantine measures may be necessary. However, even if isolation is already difficult to implement on a large scale, quarantine is even much more, and they are extremely unpopular measures. On a large scale they can only be successfully implemented with the full collaboration of prepared military personal. The difficulty of implementing these measures is easier to understand reading one of the World literature masterpiece, Boccaccio's Decameron (dealing with the consequences of the 'Black Death', the XIV century plague epidemic that swept up all Europe) than reading the cool public health protocols, however important these are.

Another important issue is the full, or as full as possible, collaboration of the general population. The objective is 
everybody seeks health services as soon as they feel sick, not keeping hidden sick or dead familiars at home. For that to be successful it is important full information disclosed, as well as respect for the religious and cultural practices of the population - in a constant dialogue and negotiation with local leaders. In this respect I share WHO opinion ${ }^{1,12}$ that the way Angola health and military authorities handled the Marburg's Uíge outbreak is an example how things shall be done.

\section{Vaccines}

The apparent protective efficacy of passive immunity against Ebola infection, both in animals models ${ }^{31}$ and in anecdotal human cases, ${ }^{16,20}$ and both by transfer of whole sera from immunized donors as well as by anti-Ebola specific immunoglobulins, is a strong suggestion of the probable protective efficacy of anti-Ebola vaccines. And there are already half a dozen different anti-Ebola vaccines in various stages of the research pipeline. ${ }^{32}$

At the time of this writing the most advanced one is the so called NIAID/GSK Ebola vaccine. It has two variants, one monovalent against Ebolavirus Zaire and the other against both $E$. Zaire and $E$. Sudan. It used only small parts of Ebola virus on a platform of chimpanzee adenovirus 3, which is unable to replicate in humans. ${ }^{33}$ It get very good results in monkey trials and it is scheduled to start human phase I trials in the second week of September $2014 .^{34}$

Also in an advanced stage is the multivalent antifilovirus vaccine NIAID/Crucell (against Marburgvirus, E. Zaire and $E$. Sudan). In its monovalent (only against $E$.
Zaire) incarnation get good results in a phase I human trial, and the multivalent is scheduled to start human trials at the end of 2015 or early 2016 . It is also a recombinant vaccine, using an adenovirus platform. ${ }^{35}$

All other vaccine candidates are in a less advanced stage. Some also use adenovirus platforms to express Ebola antigens (or both Ebola and Marburg), some use instead recombinant vesicular stomatitis virus as a delivering platform ${ }^{36}$ and even one uses rabies attenuated vaccine virus. ${ }^{37}$

Most Ebola (or Ebola/Marburg) vaccine candidates are parenteral. However there are already some Ebola vaccine candidates than can be delivered by airway, by way of a spray, with good results in animal models. ${ }^{38}$ For the moment, an oral Ebola vaccine is still a dream. The nonparenteral vaccines may prove to be very useful, not only because they may be better accepted by the populations, particularly children, but also because they may be used also in animals. And they are desperately needed for some animals: Congo Brazaville lost a large share of its major animal tourism attractor in $2001,{ }^{39}$ when an Ebola outbreak killed 130 of the $143(91 \%)$ wild gorillas from the Lossi 1 National Park and 91 of 95 (96\%) of Lossi 2 National Park!

\section{CONFLICTS OF INTEREST}

The authors declare that they had no conflicts of interest.

\section{FUNDING SOURCES}

No subsidies or grants contributed to this work.

\section{REFERENCES}

1. World Health Organization. Ebola virus disease - Fact sheet $N^{\circ} 103$ [consulted 2014 Aug 31]. Available from: http//www.who.int.

2. Centers for Disease Control and Prevention. Ebola Hemorrahagic Fever; [consulted 2014 Aug 31]. Available from: http//www.cdc.gov.

3. MacNeil A, Rollin PE. Ebola and Marburg hemorrhagic fevers: neglected tropical diseases? PLoS Negl Trop Dis. 2012;6:e1546.

4. Hartman Al. Ebola and Marburg virus infections. In: Magill AJ, Ryan ET, Hill DR, Solomon T, editors. Hunter's tropical medicine and emerging infectious diseases. London: Saunders Elsevier; 2013. p. 330-3.

5. Rey FA. Virology: one protein, many functions. Nature. 2010;468:773-5.

6. Normile D. Scientists puzzle over Ebola-Reston virus in pigs. Science. 2009;323:451.

7. Barrette RW, Metwally SA, Rowland JM, Xu L, Zaki SR, Nichol ST, et al. Discovey of swine as a host for the Reston ebolavirus. Science. 2009;325:204-6.

8. Leroy EM, Kumulunqui $B$, Pourrut $X$, Rouquet $P$, Hassanin A, Yaba $P$, et al. Fruit bats as reservoirs of Ebola virus. Nature. 2005;438:575-6.

9. Leroy EM, Pourrut $X$. On avé trouvé l'animal réservoir de le virus Ébola. La Recherche. 2006;403:68-73.

10. Towner JS, Pourrut X, Albariño CG, Nkogue CN, Bird BH, Grard G, et al. Marburg virus infection detected in a common african bat. PLoS One. 2007;2:e764

11. Kuzmin IV, Niezgoda M, Franka R, Agwanda B, Markotter W, Breiman RF, et al. Marburg virus in fruit bat, Kenya. Emerg Infect Dis. 2010;16:352-4.

12. World Health Organization Africa Regional Office. Ebola Update 2014 August 28; [consulted 2014 Aug 31]. Available from: http//www.who.afr. int.

13. Centre for Biosecurity, Public Health Agency of Canada. Ebolavirus Pathogen Safety Data Sheet; [consulted 2014 Aug 31]. Available from: http//www.phac.gc.ca/lab-bio/res/psds-ftss/ebola-eng.php.

14. Isaacson M, Sureau $P$, Courteille G, Pattyn SR. Clinical aspects of Ebola virus disease at the Ngaliema hospital, Kinshasa, Zaire, 1976;

[consulted 2014 Aug 31]. Available from: http//www.itg.be/internet/ebola/ ebola-12.htm.

15. Kortepeter MG, Bausch DG, Bray M. Basic clinical and laboratory features of filoviral hemorrhagic fever. J Infect Dis. 2011;204:S5810-6.

16. Mupapa K, Massamba M, Kibadi K, Kuvula K, Bwaka A, Kipasa M, et al. Treatment of Ebola hemorrhagic fever with blood transfusions from convalescent patients. J Infect Dis. 1999;179:S18-S23.

17. Gupta M, Mahanty S, Bray M, Ahmed R, Rollin PE. Passive transfer of antibodies protects immunocompetent and immunodeficient mice against lethal Ebola virus infection without complete inhibition of viral replication. J Virol. 2001;75:4649-54.

18. Pettitt J, Zeittlin L, Kim DH, Working C, Johnson JC, Bohorov O, et al. Therapeutic intervention of Ebola virus infection in rhesus macaques with the MB-003 monoclonal antibody cocktail. Science Transl Med. 2013;5:199ra113.

19. Qiu X, Wong G, Fernando L, Audet J, Bello A, Strong J, et al. mAbs and Ad-Vectored IFN- $\alpha$ therapy rescue Ebola-infected nonhuman primates when administered after the detection of viremia and symptons. Science Transl Med. 2013;5:207ra143.

20. CNN News. Finally found a treatment, perhaps a cure, for Ebola. CNN broadcasted on August 5, 2014

21. Sandle T. Second experimental Ebola drug gains approval. Digita Journal; [consulted 2014 Aug 31]. Available from: http//www. digitaljournal.com/print/article/395972.

22. Warfield KL, Swenson DL, Olinger GG, Nichols DK, Pratt WD, Blouch $\mathrm{R}$, et al. Gene-specific countermeasures against Ebola virus based on antisense phosphorodiamidate morpholino oligomers. PLoS Pathogens. 2006;2:e1.

23. Geisberg TW, Lee A, Robbins M, Geisbert JB, Homko A, Sood V, et al. Postexposure protection of non-human primates against a lethal Ebola virus challenge with RNA interference: a proof-of-concept study. The Lancet. 2010;375:1896-905. 
24. Warren TK, Wells J, Panchal RG, Stuthman KS, Garza NL, Tongeren $\mathrm{V}$, et al. Protection against filovirus diseases by a novel broad-spectrum nucleoside analogue BCX4430. Nature. 2014;508:402-5.

25. Geisbert TW, Hensley LE, Jahrling PB, Larsen T, Geisberg JB, Paragas $\mathrm{J}$, et al. Treatment of Ebola virus infection with a recombinant inhibitor of factor VIla/tissue factor: a study in rhesus monkeys. Lancet. 2003;362:1953-8.

26. World Health Organization. Interim infection prevention and control guidance for care of patients with suspected or confirmed filovirus haemorrhagic fever in health-care settings, with focus on Ebola. Geneve: WHO; 2014.

27. George F. Orientação da DGS nº 003/2014: Equipamentos de proteção individual para agentes biológicos de tipo 4. Lisboa: Direção-Geral de Saúde; 2014.

28. George F. Orientação da DGS n 004/2014: Doença por vírus Ebola - Procedimentos laboratoriais. Lisboa: Direção-Geral de Saúde; 2014.

29. Freitas MG. Orientação da Direção-Geral de Saúde $n^{\circ}$ 012/2014: Doença por vírus Ebola - Procedimentos a adotar pelos serviços de saúde. Lisboa: DGS; 2014.

30. CNN News. It is possible to fight Ebola in Africa. CNN. broadcasted on August 28, 2014

31. Wong G, Richardson JS, Pillet S, Patel A, Qiu X, Alimonti J, et al. Immune parameters correlate with protection against Ebola virus infection in rodents and nonhuman primates. Science Transl Med. 2012;4:158ra146.

32. National Institute of Allergy and Infectious Diseases. Research feature: Ebola/Marburg research. National Institutes of Health; [consulted 2014
Aug 31]. Available from: http//www.niaid.nih.gov/topics/ebolamarburg/ research/pages/default.aspx

33. National Institute of Allergy and Infectious Diseases. Phase 1 Clinical Trials of NIAID/GSK Investigational Ebola Vaccines. National Institutes of Health News \& Events; [consulted 2014 Aug 28]. Available from: http// www.niaid.nih.gov/news/QA/Pages/EbolaVaxQA.aspx.

34. Fox M. First human trials of Ebola vaccine starts next week. NBC News; [consulted 2014 Aug 31]. Available from: http//www.nbcnews.com/ storyline/ebola-virus-outbreak/first-human-trials-ebola-vaccine-startsnext-week-n190716.

35. Crucell Development Programs. Ebola and Marburg vaccine. Crucell; [consulted 2014 Aug 31]. Available from: http//www.crucell.com/R and_D-Clinical_Development-Ebola_Vaccine.

36. Geisberg TW, Feldmann H. Recombinant vesicular stomatitis virusbased vaccines against Ebola and Marburg virus infections. J Infect Dis. 2011;204:S1075-81.

37. National Institute of Allergy and Infectious Diseases. Rabies vaccine protects nonhuman primates against deadly Ebola virus. National Institutes of Health Research Feature; [consulted 2014 Aug 31]. Available from: http//www.niaid.nih.gov/topics/ebolamarburg/Pages/ rabiesVaccEbola.aspx.

38. Richardson JS, Pillet S, Bello AJ, Kobinger GP. Airway delivery of an adenovirus-based Ebola virus vaccine bypasses existing immunity to homologous adenovirus in nonhuman primates. J Virol. 2013;87:366877.

39. Bermejo M, Rodriguez-Teijeiro JD, Illera G, Barroso A, Vila C, Walsh PD. Ebola outbreak killed 5000 gorillas. Science. 2006;314:1564. 


\section{Ebolavirosis: a 2014 Review for Clinicians}

Acta Med Port 2014:27:625-633

Publicado pela Acta Médica Portuguesa, a Revista Científica da Ordem dos Médicos

Av. Almirante Gago Coutinho, 151

1749-084 Lisboa, Portugal.

Tel: +351218428 215

E-mail: submissao@actamedicaportuguesa.com

www.actamedicaportuguesa.com

ISSN:0870-399X | e-ISSN: 1646-0758

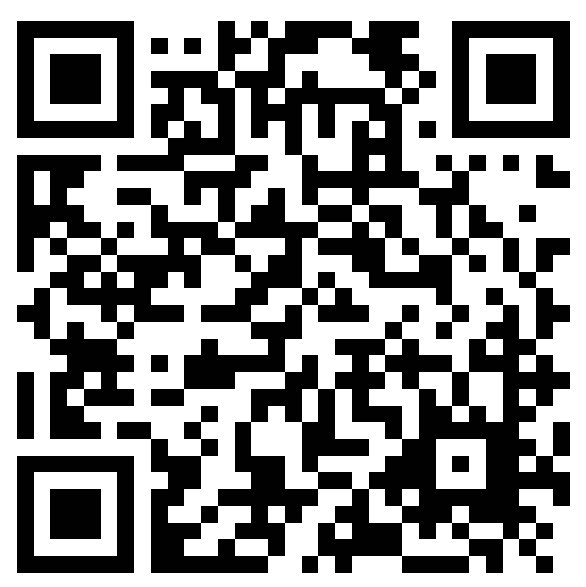

